https://ejournal.iai-tribakti.ac.id/index.php/perbankan

\title{
Pengaruh Capital Adequacy Ratio (CAR), Non Performing Loan (NPL), dan Loan to Deposit Ratio (LDR) Terhadap Return On Asset (ROA) Pada PT Bank Muamalat Indonesia
}

\section{The Influence of Capital Adequacy Ratio (CAR), Non Performing Loan (NPL), and Loan to Deposit Ratio (LDR) to Return On Asset (ROA) At the Bank Muamalat Indonesia}

\author{
Ika Nurfitriani ${ }^{1}$ \\ ${ }^{1}$ Institut Agama Islam Tribakti Kediri \\ ${ }^{1}$ ikafitrigunarsih@gmail.com
}

\begin{abstract}
The assessment of the soundness level of Sharia Commercial Banks and Sharia Business Units on a consolidated basis includes an assessment of several factors such as: risk profile, good corporate governance, profitability and capital. Return On Asset (ROA) is one of the ratios used to measure the ability of bank management to obtain overall profits, the profits earned by the company can cover possible losses in lending and trading securities activities. ROA parameter assessment can use several variables including CAR, NPL and LDR. This research is a quantitative study, using financial ratios in the form of CAR, NPL, and LDR to determine the ROA value of Bank Muamalat Indonesia, then continued with the One-Sample Kolmogorov-Smirnov Test, it can be seen that all data used in this study are normally distributed. The sample used is the monthly financial statements of Bank Muamalat Indonesia for the period January 2011 to December 2016, obtained a sample of 70 samples using purposive sampling technique. The results of the partial test in the study showed that CAR and NPL had a positive effect on ROA, while LDR had no effect on ROA with a significance level of 0.002 and a percentage of $58 \%$.
\end{abstract}

Keywords: CAR, NPL, LDR, ROA

\begin{abstract}
Abstrak
Penilaian tingkat kesehatan Bank Umum Syariah dan Unit Usaha Syariah secara konsolidasi mencangkup penilaian terhadap beberapa factor seperti: Profil resiko, Good Corporate Govermance, Rentabilitas dan permodalan. Return On Asset (ROA) adalah salah satu rasio yang digunakan untuk mengukur kemampuan manajemen bank dalam memperoleh keuntungan secara keseluruhan, keuntungan
\end{abstract}


yang diperolah perusahaan dapat menutup kemungkinan kerugian didalam kegiatan perkreditan dan perdagangan surat-surat berharga. Penilaian parameter ROA dapat menggunakan beberapa variabel diantaranya CAR, NPL dan LDR. Penelitian ini merupakan penelitian kuantitatif, dengan menggunakan rasio keuangan berupa CAR, NPL, dan LDR untuk mengetahui nilai ROA Bank Muamalat Indonesia, lalu dilanjutkan dengan uji One-Sample KolmogorovSmirnov Test dapat diketahui bahwa seluruh data yang digunakan pada penelitian ini berdistribusi normal. Sampel yang digunakan adalah laporan keuangan bulanan Bank Muamalat Indonesia periode Januari 2011 hingga Desember 2016, diperoleh sampel 70 sampel dengan menggunakan teknik purposive sampling. Hasil Uji Parsial pada penelitian menunjukkan bahwa CAR dan NPL berpengaruh positif terhadap ROA, sedangkan LDR tidak berpengaruh terhadap ROA dengan taraf signifikansi 0.002 serta prosentasi sebesar $58 \%$.

Kata Kunci: $C A R, N P L, L D R, R O A$

\section{Pendahuluan}

Dalam SE-BI 6/23/DPNP Tanggal 31 Mei 2004, pokok-pokok pengaturan tentang sistem penilaian tingkat Kesehatan bank umum. Bahwasanya dalam menilai Kesehatan perbankan ada 5 (lima) aspek yang biasa digunakan, yaitu: CAMEL (Capital, Assets, Management, Earnings dan Liquidity). ${ }^{1}$ Penilaian parameter capital hanya menggunakan satu rasio yaitu Capital Adequacy Ratio (CAR), aspek CAR digunakan untuk melihat seberapa besar bank mampu membiayai aktivitas kegiatannya dengan kepemilikan modal yang dimilikinya. ${ }^{2}$ Rasio modal bank dihitung dengan cara membandingkan antara modal bank dengan total ATMR, hasil perhitungan rasio kemudian dibandingkan dengan kebutuhan minimum yang

${ }^{1}$ Salinan Surat Edaran Otoritas Jasa Keuangan Nomor 10/SEOJK 03/2014 tentang Penilaian Tingkat Kesehatan Bank Umum Syariah dan Unit Usaha Syariah.

${ }^{2}$ Irham Fahmi. Pengantar Perbankan Teori dan Aplikasi (Bandung, ALFABETA, 2014). h. 194. 


\section{Ika Nurfitriani | Pengaruh Capital Adequacy Ratio...}

diwajibkan menurut BIS paling sedikit sebesar $8 \%$ dari total asetnya. ${ }^{3}$ Semakin tinggi permodalan maka bank tersebut berada diposisi yang sehat atau terjamin.

Selain permodalan salah satu kegiatan yang dilakukan oleh bank adalah pemberian kredit, namun pemberian kredit yang dilakukan oleh bank mengandung resiko berupa tidak lancarnya pembayaran kredit yang disebut Non Performing Loan (NPL). Rasio pembiayaan Loan to Deposit Ratio (LDR) juga dianggap menjadi tolok ukur dalam penilaian kesehatan bank. Karena rasio LDR mengindikasikan seberapa jauh kemampuan bank dalam membayar kembali penarikan dana yang dilakukan oleh deposan.

Profitabilitas dapat dikatakan sebagai salah satu indikator yang paling tepat untuk mengukur kinerja perusahaan. Rasio yang biasa digunakan untuk mengukur dan membandingkan kinerja profitabilitas perbankan adalah Return On Equity (ROE) dan Return On Asset (ROA). ${ }^{4}$ Alasan dipilihnya ROA sebagai ukuran kinerja adalah karena ROA digunakan untuk mengukur kemampuan manajemen bank dalam memperoleh keuntungan secara keseluruhan. Selain hal tersebut bagi pemodal ROA digunakan untuk mengetahui seberapa besar laba bersih yang diperoleh perusahaan dan berapa besar tingkat kembalian yang akan diterima. Semakin besar Return On Asset (ROA) suatu bank, semakin besar pula tingkat keuntungan yang dicapai bank dan semakin baik posisi bank tersebut dari segi penggunaan aset. ${ }^{5}$

Pada periode tahun 2016 Bank Muamalat Indonesia berada pada kuartal keempat dengan total pertumbuhan global sebesar $2.60 \%$, meski masih dibawah standar Bank Indonesia namun hal ini membuat Bank

${ }^{3}$ Lukman Dendawijaya. Manajemen Perbankan; Edisi Revisi (Jakarta, Ghalia Indonesia, 2009). h. 41.

${ }^{4}$ Mudrajad Kuncoro dan Suhardjono. Manajemen Perbankan; Teori dan Aplikasi. (Yogyakarta. BPFE. 2002). h. 505. 
Muamalat Indonesia menjadi bank syariah ternama yang unggul. ${ }^{6}$ Dalam Salinan Surat Edaran Otoritas Jasa Keuangan (OJK) tentang Penilaian Tingkat Kesehatan Bank Umum Syariah dan Unit Syariah, maka sudah selayaknya setiap bank perlu adanya monitoring kinerja untuk mengetahui bagaimana kinerja keuangan suatu bank, apakah dalam kategori baik atau buruk, demikian pula Bank Muamalat Indonesia. Berdasarkan laporan perkembangan Bank Muamalat Indonesia periode 2011 hingga 2016 mengalami naik turunya nilai CAR, NPL, LDR, dan ROA hal ini terlihat pada grafik berikut:

Grafik 1

Perkembangan CAR, NPL, LDR, dan ROA Bank Muamalat Indonesia

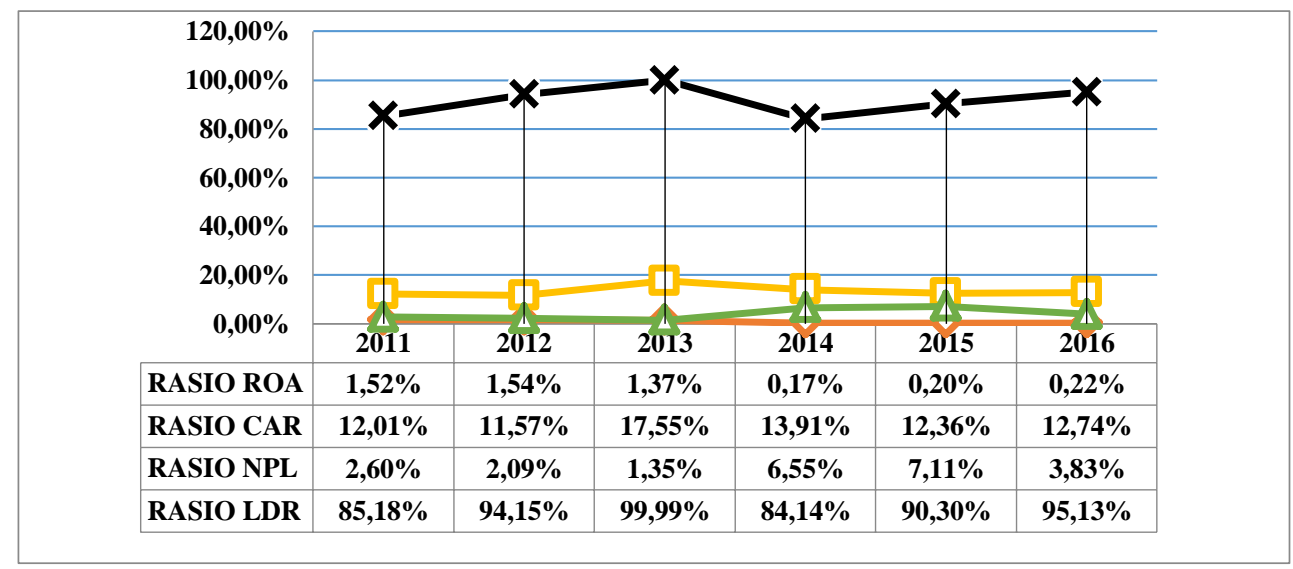

Berdasarkan garfik 1 diatas terlihat bahwa pada tahun 2012 sampai tahun 2013 ROA menurun $0.17 \%$ dari $1.54 \%$ menjadi $1.37 \%$, hal yang sama pun terjadi pada tahun 2013 sampai tahun 2014. Namun pada tahun 2014 sampai tahun 2015 mengalami peningkatan sebesar $0.03 \%$ dari $0.17 \%$ menjadi $0.20 \%$. Hal yang sama terjadi pada tahun 2015 hal ini akan berdampak buruk pada profabilitas bank. Karena dalam teori semakin besar ROA bank, semakin besar pula tingkat keuntungan yang dicapai bank

\footnotetext{
${ }^{6}$ Laporan Tahunan Bank Muamalat Indonesia Tahun 2016.
} 


\section{Ika Nurfitriani | Pengaruh Capital Adequacy Ratio...}

tersebut dan semakin baik pula posisi bank tersebut dari segi penggunaan aset. Pada garfik dibawah ini akan terlihat pula bagaimana perkembangan CAR bank Muamalat Indonesia pada tahun 2011-2016.

Untuk perkembangan CAR dari tahun ke tahun, pada tahun 2012 sampai tahun 2013 bank Muamalat Indonesia mengalami peningkatan yang sangat singnifikan yakni sebesar 5,98\% dari $11,57 \%$ menjadi $17,57 \%$, hal ini mengindikasikan bahwa bank mampu mengelola modal yang ada untuk menutup kemungkinan kerugian didalam kegiatan perkreditan dan perdagangan surat-surat berharga ${ }^{7}$

Karena semakin besar CAR maka keuntungan bank juga semakin besar. Dengan kata lain, semakin besar CAR akan berpengaruh terhadap semakin besarnya ROA bank tersebut. Akan tetapi pada grafik 1.2 terlihat bahwa nilai ROA pada tahun 2012 sampai 2013 justru mengalami penurunan sebesar $0.17 \%$, hal ini tidak sesuai dengan teori yang ada karena CAR dan ROA seharusnya berbanding lurus.

Dalam garfik juga terlihat perkembangan NPL sangat fluktuatif, pada tahun 2012 sampai tahun 2013 ketika NPL mengalami penurunan 0,74\% dari $2,09 \%$ menjadi $1,35 \%$, justru ROA mengalami penurunan sebesar $0,17 \%$. Hal yang sama juga terjadi pada tahun 2014 sampai tahun 2015 dimana ketika nilai NPL meningkat sebesar $0,56 \%$ dari $6,55 \%$ menjadi $7,11 \%$ nilai ROA juga mengalami peningkatan sebesar 0,03\%. Padahal ketika presentase NPL mengalami penurunan maka ROA yang dicapai seharusnya mengalami peningkatan, hal ini karena antara presentase NPL dan ROA berbanding terbalik

Dalam grafik diatas terlihat bahwa pada tahun 2011 sampai tahun 2012 bank Muamalat Indonesia mengalami peningkatan 8,97\% dari 85,18\%

\footnotetext{
7 Martono. Bank dan Lembaga Keuangan Lain (Yogyakarta: Cetakan Keempat Ekosinia. 2010). h. 84.
} 
menjadi 94,15\% sejalan dengan nilai ROA yang juga meningkat sebesar 0,02\%. Dan pada tahun 2012 sampai tahun 2013 nilai LDR mengalami peningkatan sebesar 5,84\% dari 94,15\% menjadi 99,99\%, berbanding terbalik dengan nilai ROA yang mengalami penurunan sebesar $0,17 \%$. Menurut teori yang ada bahwa semakin tinggi Loan to Deposit Ratio (LDR) menunjukkan semakin riskan kondisi likuiditas bank, sebaliknya semakin rendah Loan to Deposit Ratio (LDR) menunjukkan kurangnya efektifitas bank dalam menyalurkan pembiayaan.

Berdasarkan latar belakang diatas tujuan dari penelitian ini adalah pertama untuk mengetahui pengaruh Capital Adequacy Ratio (CAR) terhadap Return On Asset (ROA), kedua untuk mengetahui pengaruh Non Performing Loan (NPL) terhadap Return On Asset (ROA), ketiga untuk mengetahui Loan to Deposit Ratio (LDR) terhadap Return On Asset (ROA).

\section{Metode}

Populasi dalam penelitian ini adalah laporan keuangan publikasi Bank Muamalat Indonesia periode Januari 2011 hingga Desember 2016, sehingga diperoleh sampel sebanyak 72 sampel. Metode pengambilan sampel dalam penelitian ini metode purposive sampling. Variabel dalam penelitian ini adalah Capital Adequacy Ratio $\left(\mathrm{X}_{1)}\right.$, Non Performing Loan $\left(\mathrm{X}_{2}\right)$, Loan to Deposit Ratio $\left(\mathrm{X}_{3}\right)$ dan Return On Asset $(\mathrm{Y})$.

Penelitian ini menggunakan Analisis Regresi Linier Berganda. Tahap yang dilakukan adalah Uji F, Uji t, Uji Asumsi Klasik, Analisis Regresi Linier Berganda, Uji Koefisien Determinasi $\left(\mathrm{R}^{2}\right)$. Adapun Teknik analisis data yang digunakan adalah dengan menggunakan analisis statistik deskriptif Analisis statistik deskriptif digunakan untuk mendeskripsikan atau memberi gambaran terhadap objek yang diteliti, tujuan utama statistik deskriptif adalah 
Ika Nurfitriani | Pengaruh Capital Adequacy Ratio...

untuk menggambarkan data baik dengan tabel, grafik, maupun ringkasan data.

\section{Hasil dan Pembahasan}

Hasil analisis statistik deskriptif dapat dilihat pada Tabel 1, menunjukkan bahwa jumlah data yang digunakan dalam penelitian ini sebanyak 70 unit analisis. Hasil analisis statistik deskriptif terlihat nilai dari masing-masing variabel memiliki nilai Std. Deviation < nilai mean, maka mean dapat digunakan sebagai presentasi dari keseluruhan atau dapat dikatakan bahwa simpangan pada seluruh variabel adalah baik.

Tabel 1. Uji Statistik Deskriptif

\section{Statistics}

\begin{tabular}{lrrrrr}
\hline & \multicolumn{2}{c}{ ROA } & \multicolumn{2}{c}{ CAR } & \multicolumn{2}{c}{ NPL } & \multicolumn{2}{c}{ LDR } \\
\hline $\mathrm{N}$ & Valid & 70 & 70 & 70 & 70 \\
& Missing & 0 & 0 & 0 & 0 \\
Mean & 1.78 & 10.51 & 6.88 & 43.24 \\
Median & 2.03 & 10.39 & 7.02 & 42.42 \\
Std. Deviation & .849 & .924 & .944 & 2.421 \\
Minimum & 0 & 9 & 4 & 40 \\
\hline Maximum & 3 & 13 & 9 & 48 \\
\hline
\end{tabular}

\section{Analisis Statistik}

Sebelum dilakukan pengujian hipotesis maka harus dilakukan Uji Normalitas data atau Uji Kelayakan Data. Uji normalitas data dapat dilakukan dengan menggunakan analisis statistic One Sample Kolmologrov Smirnov. 
Tabel 2. Uji Normalitas Data

\begin{tabular}{|c|c|c|c|c|c|}
\hline \multicolumn{6}{|c|}{ One-Sample Kolmogorov-Smirnov Test } \\
\hline & & ROA & CAR & NPL & LDR \\
\hline $\mathrm{N}$ & & 70 & 70 & 70 & 70 \\
\hline \multirow{2}{*}{ Normal Parameters ${ }^{\mathrm{a}, \mathrm{b}}$} & Mean & 1.78 & 10.51 & 6.88 & 43.24 \\
\hline & Std. Deviation & .849 & .924 & .944 & 2.421 \\
\hline \multirow{3}{*}{$\begin{array}{l}\text { Most Extreme } \\
\text { Differences }\end{array}$} & Absolute & .125 & .106 & .116 & .156 \\
\hline & Positive & .077 & .081 & .085 & .156 \\
\hline & Negative & -.125 & -.106 & -.116 & -.100 \\
\hline \multicolumn{2}{|c|}{ Kolmogorov-Smirnov Z } & 1.047 & .883 & .967 & 1.301 \\
\hline \multicolumn{2}{|l|}{ Asymp. Sig. (2-tailed) } & .223 & .416 & .307 & .068 \\
\hline
\end{tabular}

Hasil uji Normalitas Data dapat disimpulkan besarnya nilai signifikansi variabel ROA, CAR, NPL, dan LDR lebih besar dari 0.05, hal ini berarti residual berdistribusi normal sehingga model regresi telah memenuhi asumsi normalitas.

\section{Uji Statistik F}

Tabel 3. Hasil Uji F

ANOVA $^{\mathrm{a}}$

\begin{tabular}{|c|c|c|c|c|c|c|}
\hline \multicolumn{2}{|c|}{ Model } & Sum of Squares & Df & Mean Square & $\mathrm{F}$ & Sig. \\
\hline \multirow{3}{*}{1} & Regression & 10.049 & 3 & 3.350 & 5.578 & $.002^{\mathrm{b}}$ \\
\hline & Residual & 39.638 & 66 & .601 & & \\
\hline & Total & 49.687 & 69 & & & \\
\hline
\end{tabular}

a. Dependent Variable: ROA

b. Predictors: (Constant), LDR, NPL, CAR

Dari perhitungan pada tabel 3 diatas dapat diketahui bahwa nilai sig. $0,002<0,05$ yang artinya $\mathrm{H}_{0}$ ditolak dan $\mathrm{H}_{1}$ diterima. Hal ini berarti secara bersama-sama CAR $\left(\mathrm{X}_{1}\right)$, NPL $\left(\mathrm{X}_{2}\right)$ dan $\operatorname{LDR}\left(\mathrm{X}_{3}\right)$ berpengaruh signifikan 


\section{Ika Nurfitriani | Pengaruh Capital Adequacy Ratio...}

terhadap ROA (Y). Dengan demikian hipotesis yang berbunyi "minimal ada salah satu variabel CAR, NPL, dan LDR yang tidak berpengaruh terhadap ROA" terbukti. Hal ini mengindikasikan ada variabel yang tidak berpengaruh terhadap ROA dan hal tersebut akan dibuktikan pada Uji t.

\section{Uji Statistik t}

Tabel 4. Hasil Uji t

\section{Coefficients $^{\mathrm{a}}$}

\begin{tabular}{|c|c|c|c|c|c|c|}
\hline \multirow{2}{*}{\multicolumn{2}{|c|}{ Model }} & \multicolumn{2}{|c|}{$\begin{array}{l}\text { Unstandardized } \\
\text { Coefficients }\end{array}$} & \multirow{2}{*}{$\begin{array}{c}\text { Standardized } \\
\text { Coefficients } \\
\text { Beta } \\
\end{array}$} & \multirow[t]{2}{*}{$\mathrm{t}$} & \multirow[t]{2}{*}{ Sig. } \\
\hline & & $\mathrm{B}$ & Std. Error & & & \\
\hline \multirow{4}{*}{1} & (Constant) & 4.105 & 1.726 & & 2.379 & .020 \\
\hline & CAR & .236 & .113 & .257 & 2.096 & .040 \\
\hline & NPL & .239 & .104 & .266 & 2.308 & .024 \\
\hline & LDR & .041 & .045 & .116 & .910 & .366 \\
\hline
\end{tabular}

Berdasarkan hasil penelitian pada tabel 4.8 maka diketahui bahwa:

a. nilai signifikansi CAR sebesar $0.040<0,05$ yang artinya $\mathrm{H}_{\mathrm{o}}$ ditolak dan $\mathrm{H}_{1}$ diterima. Berdasarkan perhitungan diatas maka CAR $\left(\mathrm{X}_{1}\right)$ secara parsial atau individu berpengaruh secara signifikan terhadap ROA (Y). Dengan demikian hipotesa yang berbunyi "CAR berpengaruh terhadap ROA" terbukti.

b. nilai signifikansi NPL sebesar $0.024<0,05$ yang artinya $\mathrm{H}_{\mathrm{o}}$ ditolak dan $\mathrm{H}_{1}$ diterima. Berdasarkan perhitungan diatas maka NPL $\left(\mathrm{X}_{2}\right)$ secara parsial atau individu berpengaruh secara signifikan terhadap ROA (Y). Dengan demikian hipotesa yang berbunyi "NPL berpengaruh terhadap ROA" terbukti. 
c. nilai signifikansi $L D R$ sebesar $0.366>0,05$ yang artinya $H_{o}$ diterima dan $\mathrm{H}_{1}$ ditolak. Berdasarkan perhitungan diatas maka LDR $\left(\mathrm{X}_{3}\right)$ secara parsial atau individu tidak berpengaruh secara signifikan terhadap ROA (Y). Dengan demikian hipotesa yang berbunyi "LDR berpengaruh terhadap ROA" tidak terbukti.

\section{Uji Multikolinieritas}

Tabel 5. Hasil Uji Multikolinieritas

\begin{tabular}{|c|c|c|c|c|}
\hline \multicolumn{5}{|c|}{ Coefficients $^{\mathrm{a}}$} \\
\hline \multirow{2}{*}{\multicolumn{2}{|c|}{ Model }} & \multicolumn{3}{|c|}{ Collinearity Statistics } \\
\hline & & Tolerance & VIF & \\
\hline \multirow{3}{*}{1} & (Cons & & & \\
\hline & CAR & 997 & & 1.003 \\
\hline & NPL & .911 & & 1.098 \\
\hline
\end{tabular}

Diketahui bahwa dalam produk regresi tidak terjadi multikolinieritas atau korelasi yang sempurna antara variabel-variabel bebas. Karena nilai VIF variabel CAR 1,003 lebih kecil dari 10, sedangkan nilai Tolerance 0.997 lebih besar dari 0,1. Pada variabel NPL nilai VIF 1,098 lebih kecil dari 10, sedangkan nilai variabel LDR dihapuskan karena hasil Uji t (Individual Test) menunjukkan bahwa LDR tidak berpengaruh.

\section{Uji Autokorelasi}

Model regresi yang baik adalah regresi yang bebas dari autokorelasi, kriteria uji dengan membandingkan nilai du dengan nilai dw dari tabel Durbin Watson.

Tabel 6. Hasil Uji Autokorelasi

\section{Model Summary $^{\mathrm{b}}$}


Ika Nurfitriani | Pengaruh Capital Adequacy Ratio...

\begin{tabular}{|c|c|c|c|c|c|}
\hline Model & $\mathrm{R}$ & $\begin{array}{c}\mathrm{R} \\
\text { Square }\end{array}$ & $\begin{array}{c}\text { Adjusted } \\
\text { R } \\
\text { Square }\end{array}$ & $\begin{array}{l}\text { Std. } \\
\text { Error of } \\
\text { the } \\
\text { Estimate }\end{array}$ & Durbin-Watson \\
\hline 1 & $.850^{\mathrm{a}}$ & .643 & .581 & 12.778 & 1.712 \\
\hline \multicolumn{6}{|c|}{ a. Predictors: (Constant), NPL, CAR } \\
\hline \multicolumn{6}{|c|}{ b. Dependent Variable: ROA } \\
\hline
\end{tabular}

Berdasarkan tabel 6, nilai Durbin Watson (dw) yang dihasilkan adalah 1.351. Selanjutnya nilai ini akan dibandingkan dengan nilai tabel signifikansi $5 \%$. Jumlah $\mathrm{N}=70$ dan jumlah variabel independen 2 maka diperoleh nilai $\mathrm{du}=1.67$ sehingga $4-\mathrm{du}=4-1.67=2,33$. Dengan demikian disimpulkan bahwa nilai du $<\mathrm{dw}<4$-du atau $1.67<1.712<2.33$, yang artinya tidak terjadi autokorelasi.

\section{Uji Heteroskedastisitas}

Berdasarkan hasil analisis data dengan menggunakan SPSS, pada gambar 1 hasil uji heteroskedastisitas diketahui bahwa tidak ada pola yang jelas, serta titik-titik menyebar diatas dan dibawah angka 0 pada sumbu $Y$, maka tidak terjadi Heteroskedastisitas.

Gambar 1. Hasil Uji Heteroskedastisitas

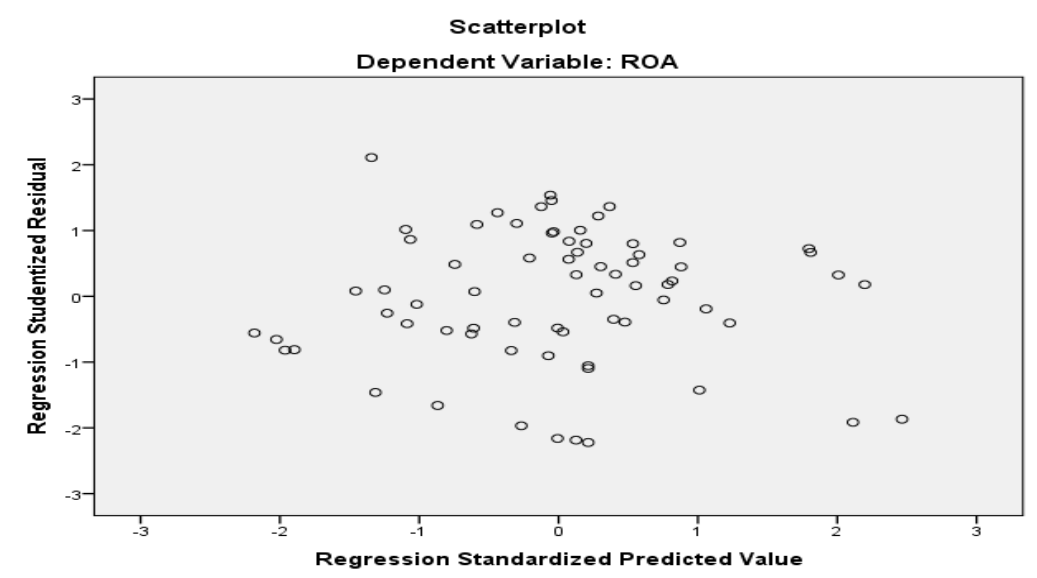




\section{Analisis Regresi Linier Berganda}

Tabel 7. Hasil Uji Regresi Linier Berganda

\begin{tabular}{|c|c|c|c|c|c|c|}
\hline \multicolumn{7}{|c|}{ Coefficients $^{a}$} \\
\hline \multirow{2}{*}{\multicolumn{2}{|c|}{ Model }} & \multicolumn{2}{|c|}{$\begin{array}{c}\text { Unstandardized } \\
\text { Coefficients }\end{array}$} & \multirow{2}{*}{$\begin{array}{c}\begin{array}{c}\text { Standardized } \\
\text { Coefficients }\end{array} \\
\text { Beta }\end{array}$} & \multirow[t]{2}{*}{$\mathrm{t}$} & \multirow[t]{2}{*}{ Sig. } \\
\hline & & $\mathrm{B}$ & Std. Error & & & \\
\hline \multirow{3}{*}{1} & (Constant) & 3.005 & 1.230 & & 2.443 & .017 \\
\hline & CAR & .281 & .101 & .306 & 2.780 & .007 \\
\hline & NPL & .267 & .099 & .297 & 2.698 & .009 \\
\hline
\end{tabular}

a. Dependent Variable: ROA

Berdasarkan tabel 7, maka dapat dibuat persamaan regresi berganda sebagai berikut: $\mathrm{Y}=3.005+0,281 \mathrm{X}_{1}+0,267 \mathrm{X}_{2}+\mathrm{e}$

Dari persamaan regresi tersebut diatas berarti bahwa:

$\mathrm{a}=3.005 \quad$ : artinya apabila variabel CAR, NPL, LDR diasumsikan tidak memiliki pengaruh sama sekali $(=0)$, maka variabel $\mathrm{Y}$ (ROA) memiliki nilai sebesar 3.005.

$b_{1}=0,281 X_{1}$ : besarnya koefisien variabel CAR adalah sebesar 0,281 artinya bahwa setiap peningkatan CAR secara positif naik 1 (satuan) akan meningkatkan ROA sebesar 0,281 dengan asumsi variabel lainya konstan.

$\mathrm{b}_{2}=0,267 \mathrm{X}_{2}$ : besarnya koefisien variabel NPL adalah sebesar 0,267 artinya bahwa setiap peningkatan NPL secara positif naik 1 (satuan) akan meningkatkan ROA sebesar 0,267 dengan asumsi variabel lainya konstan. 
Ika Nurfitriani | Pengaruh Capital Adequacy Ratio...

\section{Uji Koefisien Determinasi $\left(\mathbf{R}^{2}\right)$}

Koefisien determinasi digunakan untuk mengetahui seberapa besar presentase sumbangan pengaruh variabel independen secara bersama-sama terhadap variabel dependen. ${ }^{8}$ Nilai koefisien determinasi adalah antara nol sampai satu (0-1).

Tabel 8. Hasil Uji Koefisien Determinasi $\left(\mathrm{R}^{2}\right)$

\begin{tabular}{|c|c|c|c|c|c|}
\hline \multicolumn{6}{|c|}{ Model Summary $^{b}$} \\
\hline Model & $\mathrm{R}$ & $\begin{array}{c}\mathrm{R} \\
\text { Square }\end{array}$ & $\begin{array}{c}\text { Adjusted } \\
\text { R } \\
\text { Square }\end{array}$ & $\begin{array}{c}\text { Std. } \\
\text { Error of } \\
\text { the } \\
\text { Estimate }\end{array}$ & Durbin-Watson \\
\hline 1 & $.850^{\mathrm{a}}$ & .643 & .581 & 12.778 & 1.712 \\
\hline \multicolumn{6}{|c|}{ a. Predictors: (Constant), NPL, CAR } \\
\hline \multicolumn{6}{|c|}{ b. Dependent Variable: ROA } \\
\hline
\end{tabular}

Berdasarkan tabel diatas diketahui nilai $R$ Square adalah 0.643 . Hal ini menunjukkan bahwa nilai $R$ Square mendekati 1 (satu), maka dapat dikatakan semakin kuat variabel Capital Adequacy Ratio (CAR), dan Non Performing Loan (NPL) dalam menerangkan variabel Return On Asset (ROA). Serta diketahui nilai Adjusted $R$ Square adalah 0.581 , artinya variabel Capital Adequacy Ratio (CAR), dan Non Performing Loan (NPL), mampu menjelaskan variabel Return On Asset (ROA) sebesar 58\%. Berarti masih ada variabel lain sebesar $42 \%$ yang menjelaskan variabel Return On Asset (ROA) akan tetapi variabel tersebut tidak diteliti dalam penelitian ini.

\section{Pengaruh Capital Adequacy Ratio (CAR) Terhadap Return On Asset (ROA)}

${ }^{8}$ Ghozali. Aplikasi Analisis Multivariate dengan Program SPSS. (Semarang. Badan Penerbitan Universitas Diponegoro). h. 55. 
Capital Adequacy Ratio (CAR) adalah rasio yang digunakan untuk mengukur kemampuan permodalan yang ada untuk menutup kemungkinan kerugian didalam kegiatan perkreditan dan perdagangan surat-surat berharga. ${ }^{9}$ Besarnya CAR secara tidak langsung mempengaruhi ROA karena laba merupakan komponen pembentukan rasio ROA. Dengan demikian, semakin besar CAR akan berpengaruh terhadap semakin besarnya ROA bank tersebut. Rasio ini merupakan pembagian dari modal dengan total Aktiva Tertimbang Menurut Resiko (ATMR).

Dari hasil analisis deskriptif diketahui nilai rata-rata CAR Bank Muamalat Indonesia pada tahun 2011 sampai 2016 adalah $10.51 \%$ berada diatas standar yang ditetapkan oleh BIS. Jika nilai CAR berada di bawah standar yang ditetapkan oleh BIS maka hal ini menindikasikan bahwa modal sendiri yang dimiliki Bank Muamalat Indonesia menurun, jika modal menurun maka tingkat solvabilitas bank menurun. Dengan hipotesis Hasil uji parsial CAR adalah 0,040 $<0,05$, dari hasil penelitian tersebut menunjukkan bahwa CAR berpengaruh terhadap ROA. Tingginya nilai CAR dapst disebabkan oleh adanya penambahan modal dari pemilik yang berupa fresh money untuk mengantisipasi perkembangan skala usaha yang berupa ekspansi kredit.

\section{Pengaruh Non Performing Loan (NPL) Terhadap Return On Asset (ROA)}

Rasio ini menunjukkan kemampuan manajemen Bank dalam mengelola pembiayaan bermasalah yang diberikan oleh bank. Artinya, semakin tinggi rasio ini maka akan semakin buruk kualitas pembiayaan bank yang menyebabkan jumlah pembiayaan bermasalah semakin besar.

${ }^{9}$ Martono. Bank dan Lembaga Keuangan Lain. (Yogyakarta. Cetakan Keempat Ekosinia.2010). h.84. 


\section{Ika Nurfitriani | Pengaruh Capital Adequacy Ratio...}

Pembiayaan bermasalah menggunakan suatu situasi dimana persetujuan pengembalian pembeiyaan mengalami resiko kegagalan, bahkan cenderung menuju atau mengalami kerugian yang potensial. Nilai NPL dapat diperoleh dengan membandingkan rasio pembiayaan non lancer terhadap total pembiayaan.

Hasil nalisis diketahui bahwa nilai rata-rata NPL Bank Muamalat Indonesia periode 2011-2016 adalah 6,88\%. Rata-rata tersebut masih dalam batas aman NPL yang disyaratkan oleh Bank Indonesia, oleh karena itu kenaikan NPL tidak mengakibatkan menurunya ROA karena nilai Penyisihan Penghapusan Aktiva Produktif (PPAP) masih dalam mengcover kredit bermasalah. Sedangkan hasil uji t variabel NPL adalah $0,024<0,05$. Kondisi ini membuktikan bahwa semakin tinggi nilai NPL perusahaan maka mengakibatkan semakin tinggi ROA.

\section{Pengaruh Loan to Deposit Ratio (LDR) Terhadap Return On Asset (ROA)}

Loan to Deposit Ratio (LDR) menyatakan seberapa jauh kemampuan Bank dalam membayar kembali penarikan dana yang dilakukan masyarakat dengan mengandalkan pembiayaan yang diberikan sebagai sumber likuiditasnya. ${ }^{10}$ Artinya seberapa jauh pemberian pembiayaan kepada nasabah pembiayaan dapat mengimbangi kewajiban bank untuk dapat segera memenuhi permintaan deposan yang ingin menarik kembali dananya yang telah digunakan oleh bank untuk memberikan pembiayaan.

Hasil analisis perkembangan Bank Muamalat Indonesia sebesar 43,24\%, menunjukkan rata-rata nilai LDR memenuhi standar yang ditetapkan oleh Bank Indonesia. Menurut pendapat kamsir semakin tinggi rasio LDR memberikan indikasi rendahnya likuiditas bank, karena dana bank lebih

\footnotetext{
${ }^{10}$ Rivai dan Andria Permata Veithzal. Credit Management Handbook. (Jakarta. PT Raja Gafindo Persada. 2006). h. 156.
} 
banyak digunakan untuk memberikan pembiayaan dari pada diinvestasikan dalam bentuk kas. ${ }^{11}$ Hasil uji parsial menunjukkan bahwa LDR tidak berpengaruh terhadap ROA dengan nilai signifikansi sebesar 0,366 >0.05. Hal ini dapat terjadi sebab pihak manajemen bank kurang menerapkan prinsip kehati-hatian dalam menilai calon nasabah yang melakukan pengajuan pembiayaan.

\section{Pengaruh CAR, NPL, dan LDR Terhadap Return On Asset (ROA)}

Rasio ini digunakan untuk mengukur kemampuan perusahaan dalam memperoleh keuntungan (laba), semakin besar ROA maka semakin besar pula keuntungan yang dicapai bank tersebut dan semakin baik pula posisi bank tersebut dari segi penggunaanya. ROA memfokuskan kemapuan perusahaan untuk memperoleh profit dalam kegiatan operasi perusahaan dengan memanfaatkan aktiva yang dimilikinya. Analisis deskriptif variabel ROA periode Januari 2011 hingga Desember 2016 sebesar 1,78\% yang artinya bank Muamalat Indonesia berada pada peringkat ke-1 berdasarkan pemeringkat Surat Edaran Bank Indonesia No. 9/24/DPbS.

Hasil uji simultan (uji F) ada 3 variabel yang berpengaruh terhadap ROA, yakni CAR, NPL dan LDR. Dibuktikan dengan hasil uji statistik nilai singnifikansi sebesar 0,002 lebih kecil dari taraf signifikansi sebesar 0,05, hal tersebut membuktikan bahwa hipotesis "diduga ada pengaruh yang singnifikan dari CAR, NPL, dan LDR terhadap ROA” diterima.

\section{Kesimpulan}

Berdasarkan analisis data dan pembahasan yang telah dikemukakan dapat disimpulkan dari penelitian ini bahwa hasil uji $\mathrm{F}$ variabel yang 2008). h. 290. 


\section{Ika Nurfitriani | Pengaruh Capital Adequacy Ratio...}

mempengaruhi ROA adalah CAR, NPL, dan LDR sehingga hipotesis yang berbunyi "minimal ada satu variabel CAR, NPL, dan LDR yang tidak berpengaruh terhadap ROA" diterima. Hasil uji F tersebut kemudian dibuktikan dengan Uji t (Uji parsial).

Berdasarkan hasil analisis data diketahui bahwa Bank Muamalat Indonesia pada periode 2011-2016 memiliki nilai CAR dengan nilai rata-rata sebesar $10.51 \%$, serta hasil uji parsial CAR adalah 0,040<0,05. memberikan kesimpulan bahwa pengaruh CAR terhadap ROA signifikan, maka $\mathrm{H}_{0}$ diterima Ha ditolak. Keputusan yang dihasilkan adalah hipotesis "ada pengaruh signifikan dari variabel CAR terhadap ROA"diterima.

Pada uji parsial NPL sebesar $0,024<0,05$ dengan nilai rata-rata $6.88 \%$, memberikan kesimpulan bahwa pengaruh NPL terhadap ROA signifikan, maka $\mathrm{H}_{0}$ diterima Ha ditolak. Keputusan yang dihasilkan adalah hipotesis "ada pengaruh signifikan dari variabel NPL terhadap ROA"diterima.

Pada uji parsial LDR sebesar 0,366>0,05 dengan nilai rata-rata 43.24\%, memberikan kesimpulan bahwa pengaruh LDR terhadap ROA tidak signifikan, maka $\mathrm{H}_{0}$ ditolak Ha ditolak. Keputusan yang dihasilkan adalah hipotesis "ada pengaruh signifikan dari variabel LDR terhadap ROA" ditolak.

\section{Daftar Pustaka}

Imam Ghozali. Aplikasi Analisis Multivariate dengan Program SPSS. Semarang: Badan Penerbit Universitas Diponegoro, 2005.

Irham Fahmi, Pengantar Perbankan Teori dan Aplikasi. Bandung: ALFABETA, 2014.

Kamsir. Bank dan Lembaga Keuangan Lainya. Jakarta: PT Raja Gafindo Persada, 2008.

Laporan Tahunan Bank Muamalat Indonesia Tahun 2016. 
Ika Nurfitriani | Pengaruh Capital Adequacy Ratio...

Lukman Dendawijaya. Manajemen Perbankan; Edisi Revisi. Jakarta: Ghalia Indonesia, 2009.

Martono. Bank dan Lembaga Keuangan Lain. Yogyakarta: Cetakan Keempat Ekosinia, 2010.

Rivai, Andria Permata Veithzal. Credit Management Handbook. Jakarta: PT Raja Gafindo Persada. 206.

Salinan Surat Edaran Otoritas Jasa Keuangan Nomor 10/SEOJK 03/2014 tentang Penilaian Tingkat Kesehatan Bank Umum Syariah dan Unit Usaha Syariah. 